\title{
Functional Damage Assessment Visually on the Road Using Pavement Condition Index (PCI)
}

\author{
Emil Adly ${ }^{{ }^{*}}$, Anita Rahmawati ${ }^{1}$, Dian Setiawan ${ }^{1}$, Siska Dewi $^{1}$, Wahyu Widodo ${ }^{1}$ \\ ${ }^{I}$ Department of Civil Engineering, Universitas Muhammadiyah Yogyakarta, Indonesia \\ *Corresponding author.Email: emil@umy.ac.id
}

\begin{abstract}
The road is a land transportation infrastructure essential in facilitating the social and economic activities of the community. Wellconstructed road conditions will equip population mobility in social activities and relations. However, road damage at low and high levels will not only obstruct social and economic activities but also cause accidents. Any road pavement structure will undergo a gradual destruction process since the road was first opened for traffic. Overcoming this phenomenon requires a method to determine a road maintenance program that can be prepared using the Pavement Condition Index (PCI). The case study of this research is on Triwidadi Street, Pajangan, Bantul, Yogyakarta, and located $14 \mathrm{~km}$ from the zero-point of Bantul Regency. This study reviewed the four-kilometer road. The analysis results revealed that the PCI segment value was 34.75 , categorized as very poor. Moreover, the highest percentage value among the 13 types of road damage was Longitudinal Crack with $22.07 \%$.
\end{abstract}

Keywords—Function Damage, Pavement Condition Index (PCI), Road Assessment, Road Damage

\section{INTRODUCTION}

Road infrastructure plays a vital role in supporting human activities, such as the availability of adequate road networks and the ability to more efficiently and cheaply connect the transportation flow of goods and services to enter the city or vice versa [1]. A good road has fine surface and structural conditions [2]. The maintenance of transportation assets has become the most difficult challenge for most transportation agencies in the world [3]. In general, road damage is usually caused by age, inundation on the road surface that cannot flow due to poor drainage, and excessive repetitive traffic loads causing the road life to be shorter than planned [4]. Roads overloaded due to the continuous burden of volumes and traffic greater than planned will reduce the strength of the road pavement structure [2].The road Pavement Condition Index (PCI) will decrease with the increase in traffic loads per year [5].

The road becoming the object of discussion in this study is Triwidadi Street, Pajangan, Bantul, Yogyakarta road section, located $14 \mathrm{~km}$ from the zero-point of Bantul Regency. The expanse of land is in the form of a hilly and mountainous area. It is a regency road with secondary local road functions. There are many tourist destinations at these locations, such as Selarong Cave, coconut shell craft, Pulosari Ravine, Ngembel spring tourism, and etc. This excellence is crucial to support the economic cycle of the people concerned.

This study analyzed the road conditions, the type of road damage, and the density of road damage on the surface layer visually using the PCI method. PCI is among the most frequently used pavement efficiency measurement. It has been used as an indicator of the pavement condition [6]. PCI is the level of the pavement surface conditions and the size of the useful power function, referring to the condition and damage to the pavement surface. PCI is a visual survey method to rate the types of failure on the road surface [7].

On the flexible pavement, the type of damage can be divided into three categories and further classified into six types of cracks, lines, and holes, as well as surface defects with five types, and have a repair model based on the three PCI scales, namely preventive maintenance, large maintenance, and reconstruction [8].

Utilized the PCI as a measuring tool to determine pavement maintenance strategies based on the distress survey. It provided a simple approach to develop the PCI for selected arterial road stretches to take cost-effective maintenance measures or treatments [9]. PCI is a numerical index from 0 to 100 in which the value of 0 indicates the worst pavement condition, and 100 represents the best condition. In this method, the level of pavement damage severity is the function of three main factors comprising type of damage, damage severity, and amount or density of damage

\section{RESEARCH METHOD}

The method applied was visually carried out in the field by assessing the damage occurring on the flexible pavement. Furthermore, the results were analyzed using the Pavement Condition Index (PCI). The index obtained was used as a 
reference in recommending appropriate treatment for the authorities.
000, was carried out on Triwidadi Street, Pajangan, Bantul, Yogyakarta, $4 \mathrm{~km}$ length, with flexible pavement and 4 meters width. The research location can be seen in Fig.1.

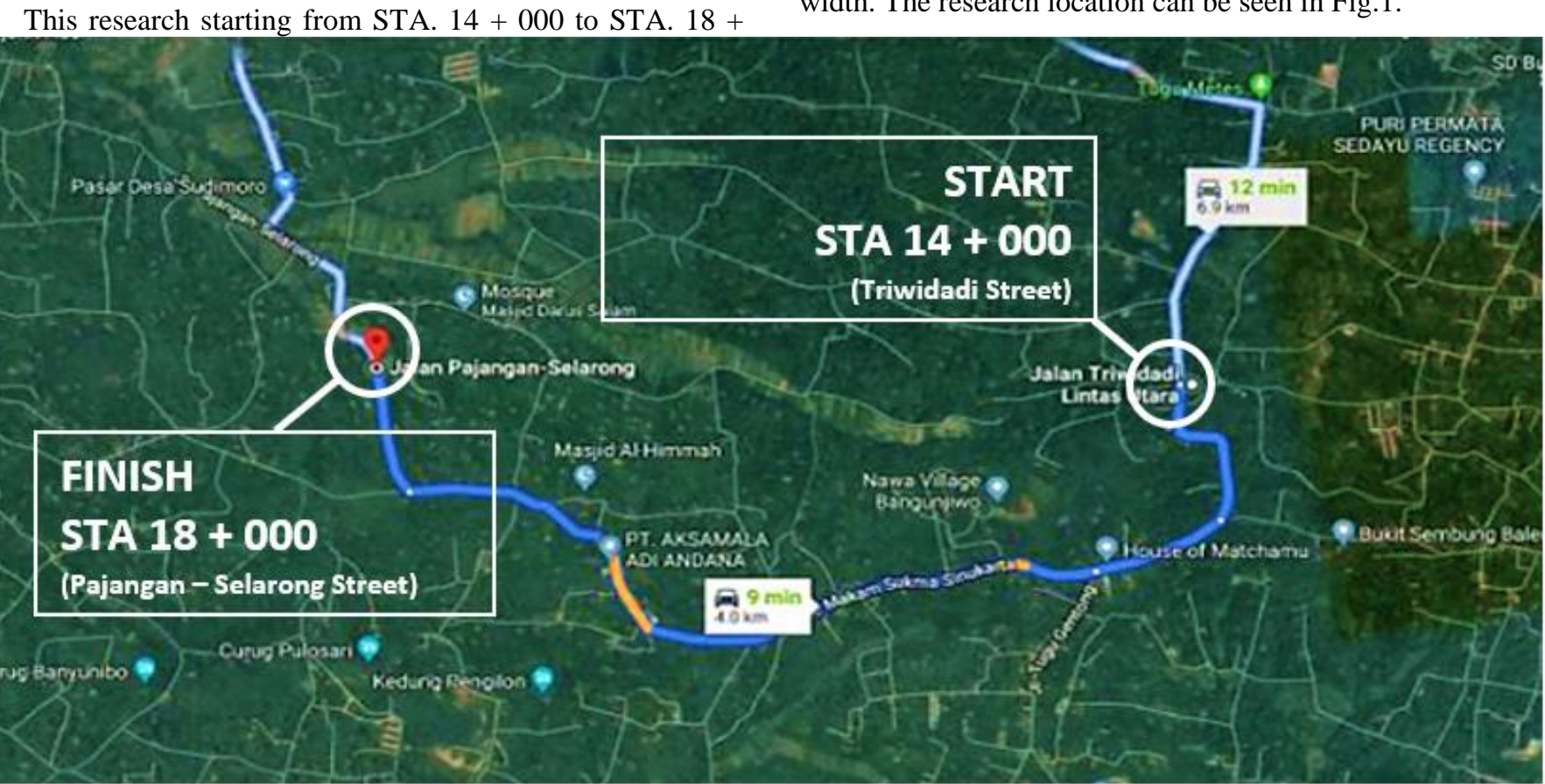

Fig. 1. Research location in Triwidadi road section, Pajangan, Bantul [10]

\subsection{Terms in PCI Calculation}

The road damage data were collected by measuring and observing at the study site. Observed data were road dimensions, road length, damage types, damage dimensions, and the severity level. Data on existing roads can determine the pavement deterioration types according to the PCI standard procedure and the severity level. The data were then calculated to obtain the deduct value (DV), the maximum data allowed (m), and the corrected deduct value (CDV). The PCI value was obtained by subtracting 100 with the total CDV. The PCI value for each segment is the PCI average of the number of segments [5].

Several terms in the PCI calculation using [11] are as follows:

\subsubsection{Deduct Value (DV)}

It is a deduction for each damage type obtained from the density curve and damage severity level.

\subsubsection{Density}

It is the percentage of the total area or length of one damage type to the total area or total length of the measured road. Thus, the damage density is expressed in the following equation:

$\left.\operatorname{Density}(\%)=\frac{A d}{A s} \times 100\right)$ or $\frac{L d}{A s} \times 100$

Ad: total area of one pavement type for each damage severity $\left(\mathrm{ft}^{2}\right.$ or $\left.\mathrm{m}^{2}\right)$
As: the total area of the sample unit ( $\mathrm{ft} 2$ or $\mathrm{m} 2$ )

Ld: total length of damage for each damage severity ( $\mathrm{ft}$ or $\mathrm{m}$ ).

\subsubsection{Total Deduct Value (TDV)}

It is the total number of DV in each sample unit.

\subsubsection{Corrected Deduct Value (CDV)}

It isobtained from the curve of the relationship between TDV and DV by selecting the appropriate curve value.

PCIs $=100-\mathrm{CDV}$

The overall PCI value of pavement in a particular road section is calculated by the equation below:

$$
\begin{aligned}
& \text { PCIf }=\text { average PCI values from all study areas } \\
& \text { PCIs }=\text { PCI value for each sample unit } \\
& \mathrm{N} \quad \text { number of a sample unit }
\end{aligned}
$$

The PCI value for each research unit depicts the unit segment pavement quality based on certain conditions. The amount of PCI value is shown in Fig. 2.

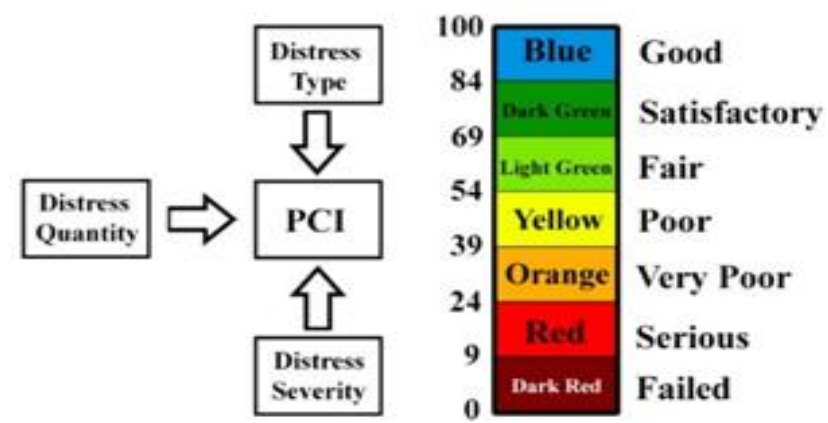

Fig. 2 Pavement condition index (PCI) scale [11] 


\subsection{Types of Road Surface Damage}

There are 19 types of damage using the PCI method [11], described in Table I.

Table I. Type of Damage [11]

\begin{tabular}{|c|c|c|}
\hline \multicolumn{3}{|l|}{ No } \\
\hline 1 & Alligator cracking & $\begin{array}{l}\text { Cracking with tissue-shape from many small } \\
\text { polygons like crocodile skin }\end{array}$ \\
\hline 2 & Bleeding & $\begin{array}{l}\text { The used impact of excessive asphalt binder, } \\
\text { expanding onto the pavement surface }\end{array}$ \\
\hline 3 & Block cracking & A crack of beams or boxes on pavements \\
\hline 4 & Bump and sags & $\begin{array}{l}\text { Small landslides and top-down cracking } \\
\text { displacements in the pavement layer form a } \\
\text { basin. }\end{array}$ \\
\hline 5 & Corrugation & $\begin{array}{l}\text { Caused by plastic deformation producing } \\
\text { transverse waves or perpendicular to the } \\
\text { asphalt pavement }\end{array}$ \\
\hline 6 & Depression & $\begin{array}{l}\text { The deformation of pavement occurring in a } \\
\text { limited area that may be followed by cracks }\end{array}$ \\
\hline 7 & Edge cracking & $\begin{array}{l}\text { This cracking occurs due to weak contraction } \\
\text { at the edge of pavement or high water } \\
\text { humidity. }\end{array}$ \\
\hline 8 & $\begin{array}{l}\text { Joint reflect } \\
\text { cracking }\end{array}$ & $\begin{array}{l}\text { This distress generally occurs at asphalt } \\
\text { pavement laid on portland cement concrete } \\
\text { pavement. }\end{array}$ \\
\hline 9 & $\begin{array}{l}\text { Lane/shoulder } \\
\text { drop off }\end{array}$ & $\begin{array}{l}\text { This damage occurs due to the presence of a } \\
\text { height difference between the surface of the } \\
\text { pavement and the surface of the roadside or the } \\
\text { surrounding soil. }\end{array}$ \\
\hline 10 & $\begin{array}{l}\text { Longitudinal/trans } \\
\text { verse cracking }\end{array}$ & $\begin{array}{l}\text { This damage consists of various damage types, } \\
\text { as the name implies, longitudinal and } \\
\text { transverse cracks on the pavement. }\end{array}$ \\
\hline 11 & $\begin{array}{l}\text { Patching and } \\
\text { utility cut } \\
\text { patching }\end{array}$ & The surface course of the pavement repaired. \\
\hline 12 & $\begin{array}{l}\text { Polished } \\
\text { aggregate }\end{array}$ & $\begin{array}{l}\text { Caused by the repeated traffic applications, } \\
\text { which may lead to the aggregate on the } \\
\text { pavement becomes polished. }\end{array}$ \\
\hline 13 & Pothole & $\begin{array}{l}\text { Shaped like a bowl that can hold and absorb } \\
\text { water on the road }\end{array}$ \\
\hline 14 & Railroad crossing & $\begin{array}{l}\text { The decrease or lump around or between rails } \\
\text { caused by differences in material } \\
\text { characteristics. }\end{array}$ \\
\hline 15 & Rutting & $\begin{array}{l}\text { Another term used to refer to this damage is } \\
\text { longitudinal ruts or channel. }\end{array}$ \\
\hline 16 & Shoving & $\begin{array}{l}\text { The displacement of the pavement layer in } \\
\text { certain parts caused by traffic loads. }\end{array}$ \\
\hline 17 & Slippage cracking & A crack like a crescent moon or half a month \\
\hline 18 & Swell & $\begin{array}{l}\text { Having a characteristic of protruding out along } \\
\text { the gradual pavement layer about } 10 \text { feet long } \\
(10 \mathrm{~m}) \text {. }\end{array}$ \\
\hline 19 & $\begin{array}{l}\text { Weathering/ } \\
\text { raveling }\end{array}$ & $\begin{array}{l}\text { Caused by a pavement layer losing asphalt or } \\
\text { tar binding, and the aggregate particles are } \\
\text { uprooted. }\end{array}$ \\
\hline
\end{tabular}

\section{RESULTS AND DISCUSSION}

\subsection{Road Condition Survey}

Road condition survey on Triwidadi Street, Pajangan, Bantul, with flexible pavement. Widh of the road 4 meters, and the length of the road 4000 meters. Road link devided into section or segmental per 50 meters according to some consideration those are to make work easier in identification and considering surveyor are not experted. Besides, measuring every 50 meters will make it easier to carry out further research development using other NDT tools, such as what researchers have done using the banklemenbeam tool [4].

\subsection{Analysis of the Road Pavement}

The steps of the PCI calculation are as follows:

1. Collecting the secondary data of all the required data such as the map of road location, road classification, and the history of road accidents in the last five years.

2. Recording road condition and damage by filling in data on the types of road damage to the PCI form

3. Recapitulating data of PCI STA. 2. $14+000-14+050$ per $50 \mathrm{~m}$, as shown in Fig. 3.

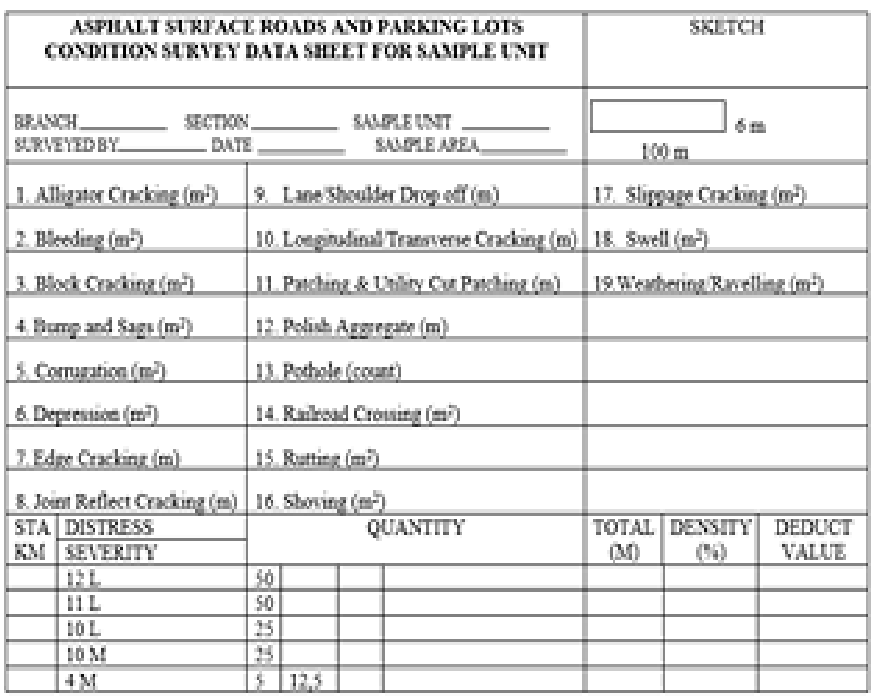

Fig. 3 Example of PCI Survey Form

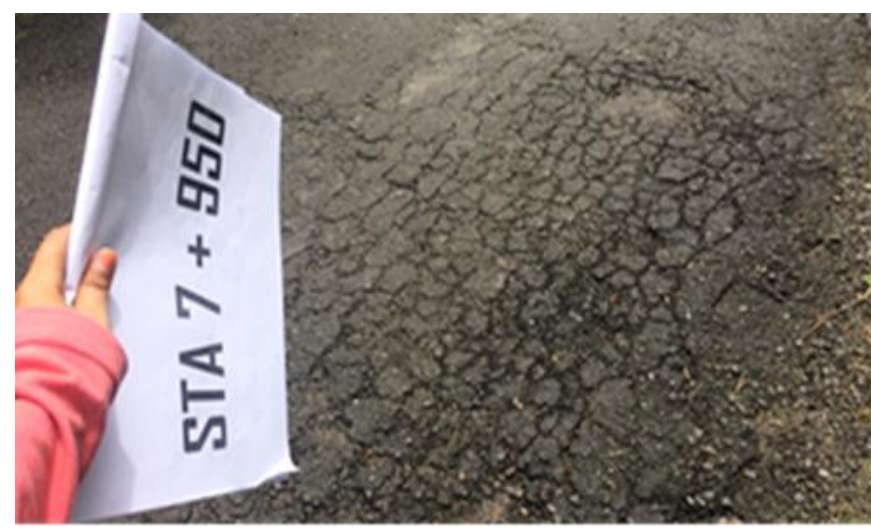

Fig. 4 Alligator Cracking at the location STA 7+950

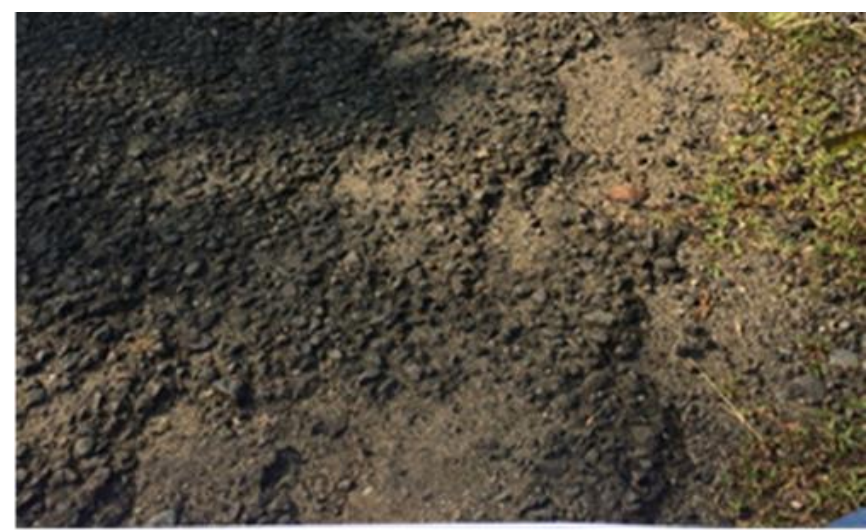

Fig. 5 Weathering and ravelling at the location 


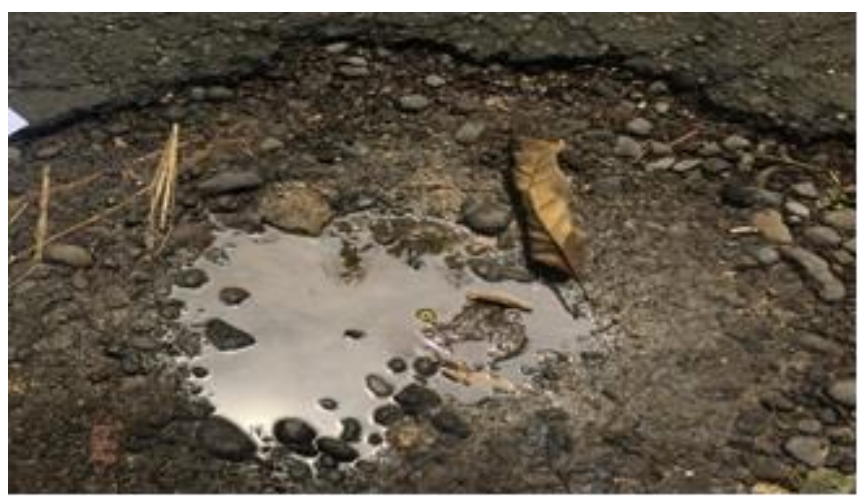

Fig. 6 Potholes at the location

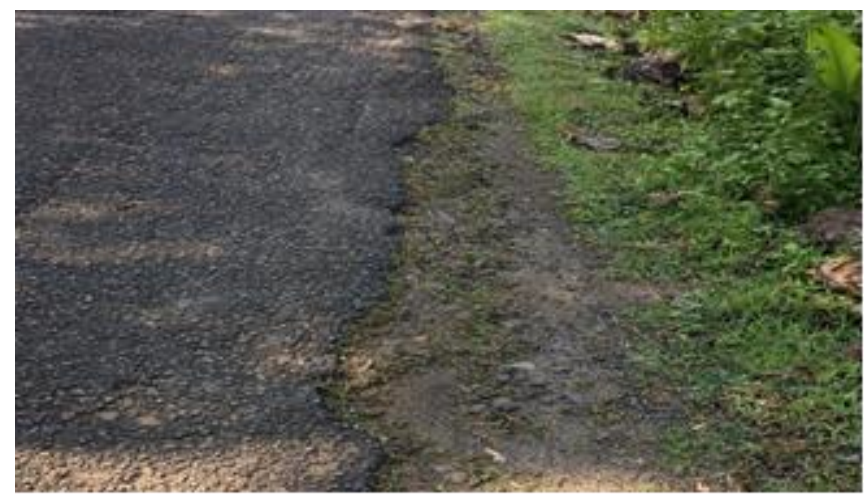

Fig. 7. Edge cracking at the location

Figure 4, 5, 6 and 7 display some of the types of damage that exist in the field. It is very clear from the picture above that the damage is in alligator cracking, weathering, raveling, potholes, edge cracking, and still a lot of damage but cannot be displayed as a whole. Interestingly, this road is quite visually apprehensive; this will impact the comfort of road users.

One of the road damages was caused by water. Water not only damages the function but also damages the structure of the road. The absence of drainage, the inadequate cross-slope of the road can cause puddles in the road, and water will seep in to disrupt the road's stability and strength.

\subsection{Data Analysis}

\subsubsection{Deduct Value (DV)}

The procedure for determining the DV consists of:

a) Adding up and noting each damage type for each damage level

b) Dividing the calculation of the total damage value by the total of road segment (in percent)

c) Determining the DV for every damage

e.g., Total quantity on STA. $14+000-14+050$, the damage is as follows:

a) Polished Aggregate $(L)=50 \mathrm{~m}$

b) Patch $(\mathrm{L})=50 \mathrm{~m}$

c) Longitudinal/ Transverse cracks $/(\mathrm{L})=25 \mathrm{~m}$

d) Longitudinal/ Transverse cracks $/(\mathrm{M})=25 \mathrm{~m}$ e) Bumps and Sags $(\mathrm{M})=5 \mathrm{~m}, 12.5 \mathrm{~m}$

\subsubsection{Calculating the Density}

Density value STA. $14+000-14+050$ is as follows:

a) Polished Aggregate (L)

$$
=(50 /(4 \times 50) \times 100 \%)=25 \%
$$

b) Patch (L)

$$
=(50 /(4 \times 50) \times 100 \%)=25 \%
$$

c) Longitudinal/ Transverse Crack (L)

$$
=(25 /(4 \times 50) \times 100 \%)=12.5 \%
$$

d) Longitudinal/ Transverse Crack (M)

$$
=(25 /(4 \times 50) \times 100 \%)=12.5 \%
$$

e) Bumps and Sags (M)

$$
=(17.5 /(4 \times 50) \times 100 \%)=8.75 \%
$$

\subsubsection{Calculating the Deduct Value (DV)}

The DV was determined by adding the percentage of density in the graphic of each damage type, followed by drawing a vertical line until it met the damage level line (low, medium, high). At the intersection point, a horizontal line was drawn. The calculation of the DV of STA. $14+000-14+050$ is provided from Fig. 8 to Fig. 12.

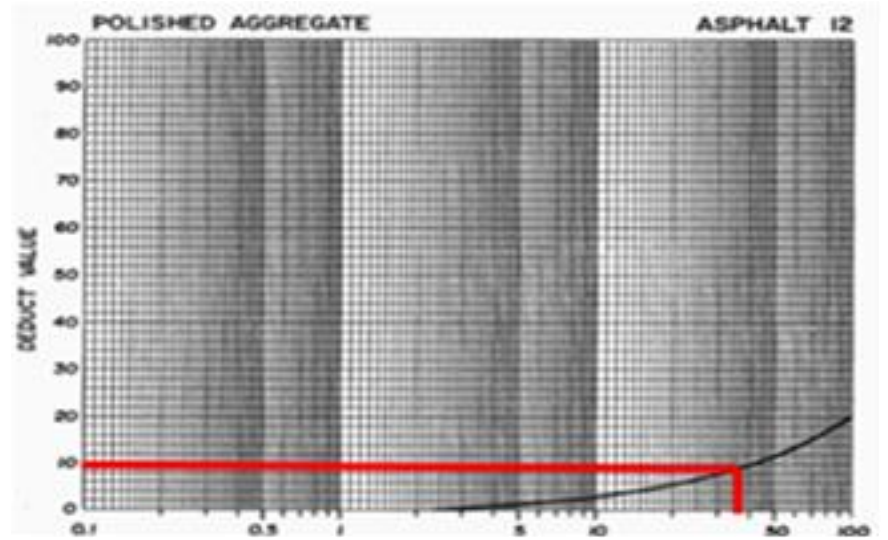

Fig. 8. The Graph of Deduct Value Polished Aggregate, L

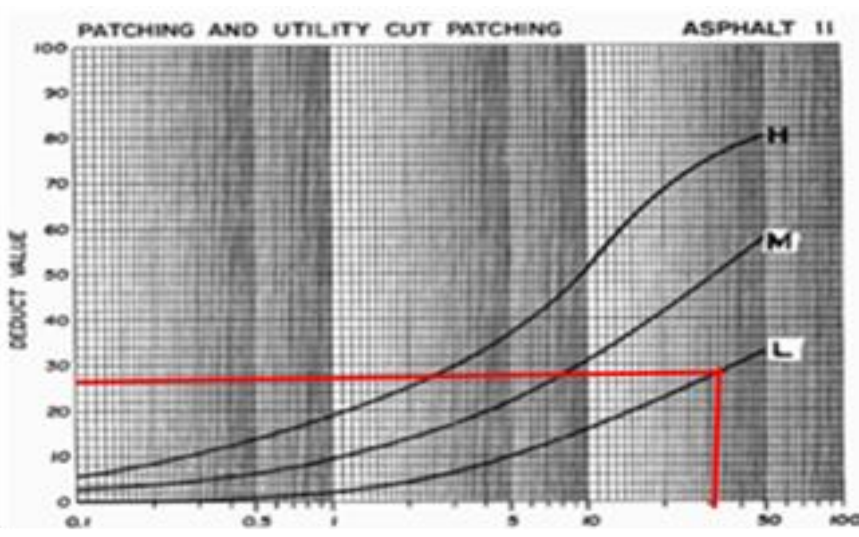

Fig. 9. The graph of Deduct Value Patch, L 


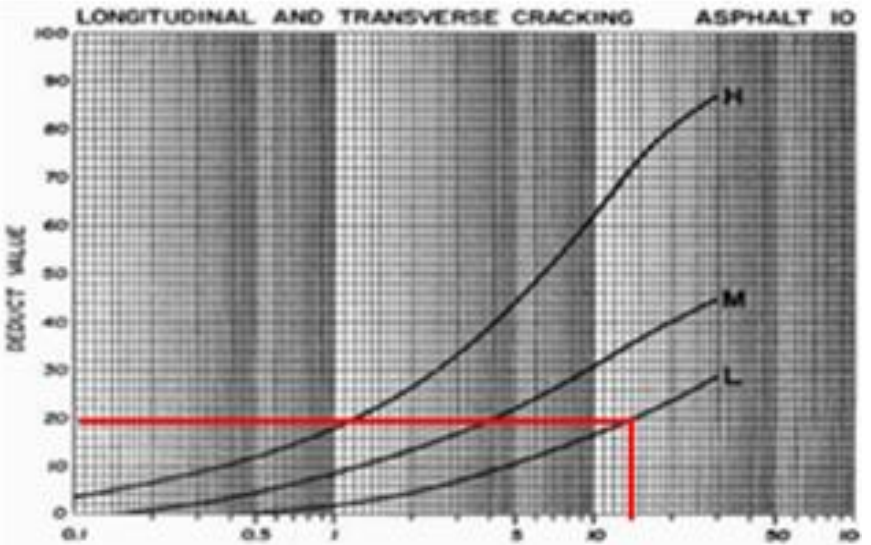

Fig. 10. The graph of Deduct Value Longitudinal Crack, L

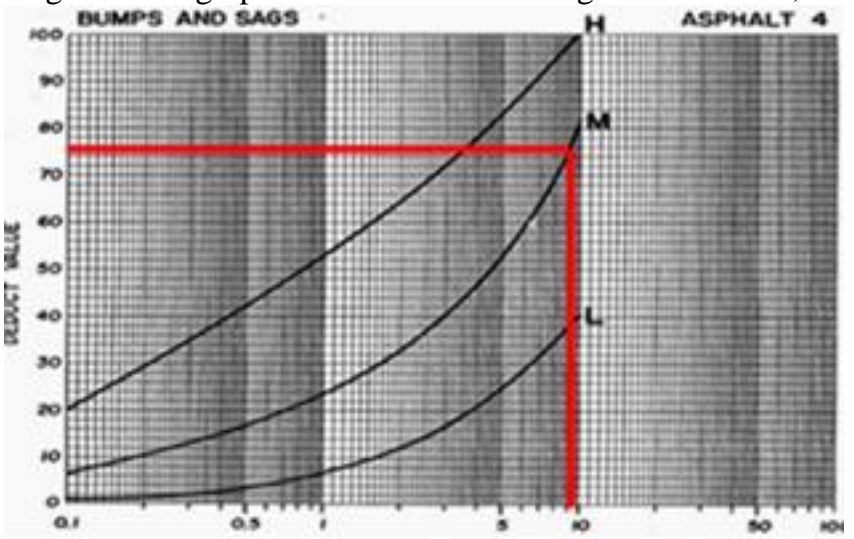

Fig. 11. The Graph of Deduct Value Bumps and Sags, M

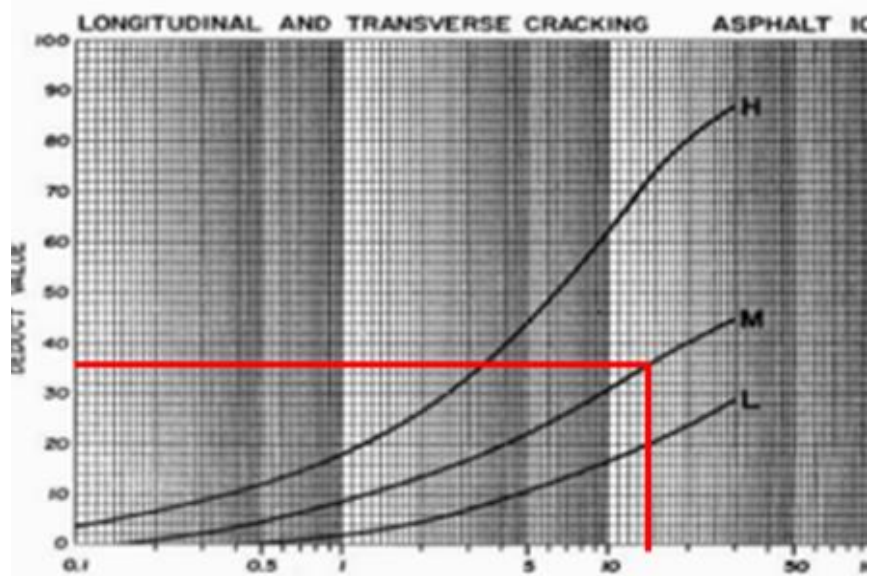

Fig. 12. The graph of Deduct Value Longitudinal Crack.

\subsubsection{Calculating the Corrected Deduct Value $(C D V)$}

For example, the STA. $14+000-14+050$, with a TDV value of 156, and a q value of 5 (greater than 2) results in a CDV value of 79, as shown in the CDV graph in Fig. 12.

Table II. The Calculation of Corrected Deduct Value (CDV)

\begin{tabular}{|c|c|c|c|c|c|c|c|c|}
\hline STA & \multicolumn{3}{|c|}{ DEDUCT VALUE (DV) } & Tot & Q & CDV \\
\hline $\begin{array}{c}14+000 \\
- \\
14+050\end{array}$ & 7 & 25 & 18 & 33 & 73 & 156 & 5 & 79 \\
\hline
\end{tabular}

Then, inserting the TDV and q value into the graph

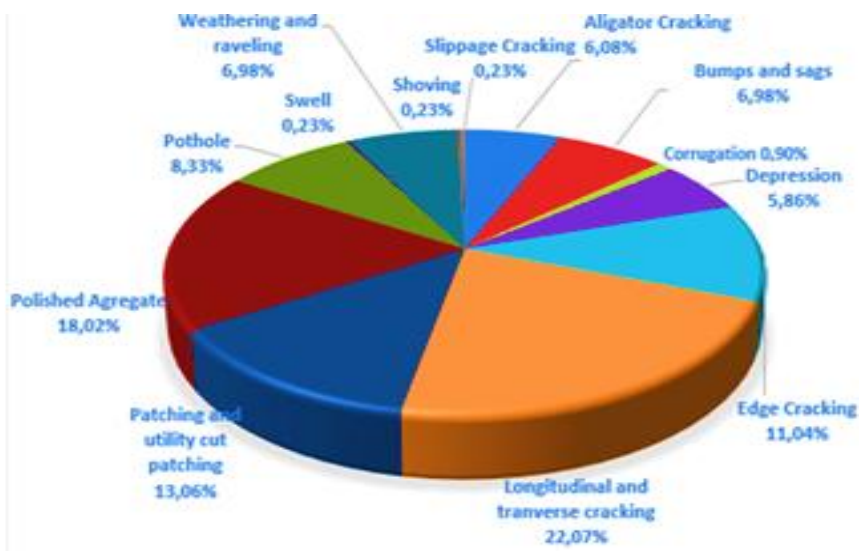

Fig. 13. Percentage of road damage

Fig. 13 displays damage of road in percentage. It is very clear from the figure that there are 13 types of damage. The percentage of written damage with a large amount of damage incurred was $22.07 \%$ longitudinal and transverse cracking, polished aggregate, patching, edge cracking $18.02 \%, 13.06 \%$, and $11.04 \%$, respectively. Another road damage is a pothole, swell, weathering/raveling, shoving, slippage cracking, alligator cracking, bumps and sag, corrugation, depression, and the amount of damage is below $10 \%$.
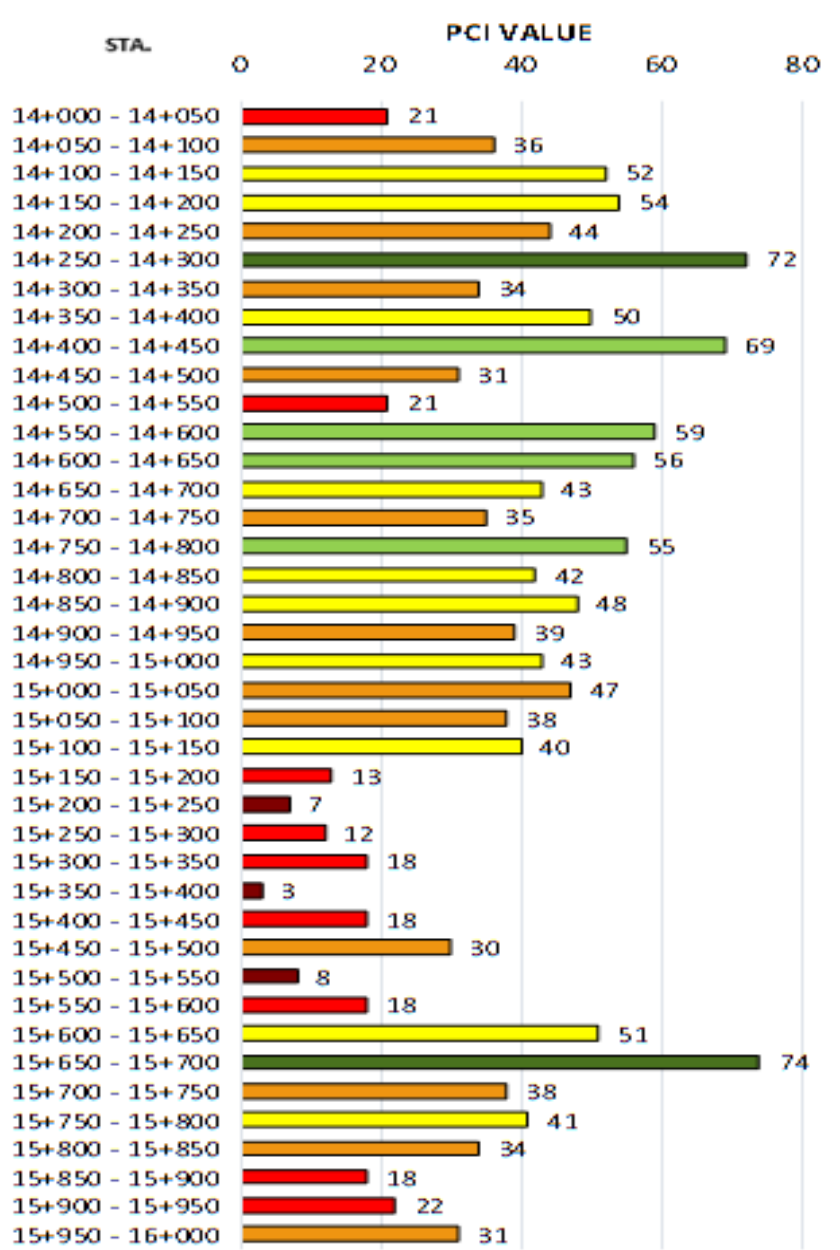

Fig. 14. STA $14+000-$ STA $16+000$ 


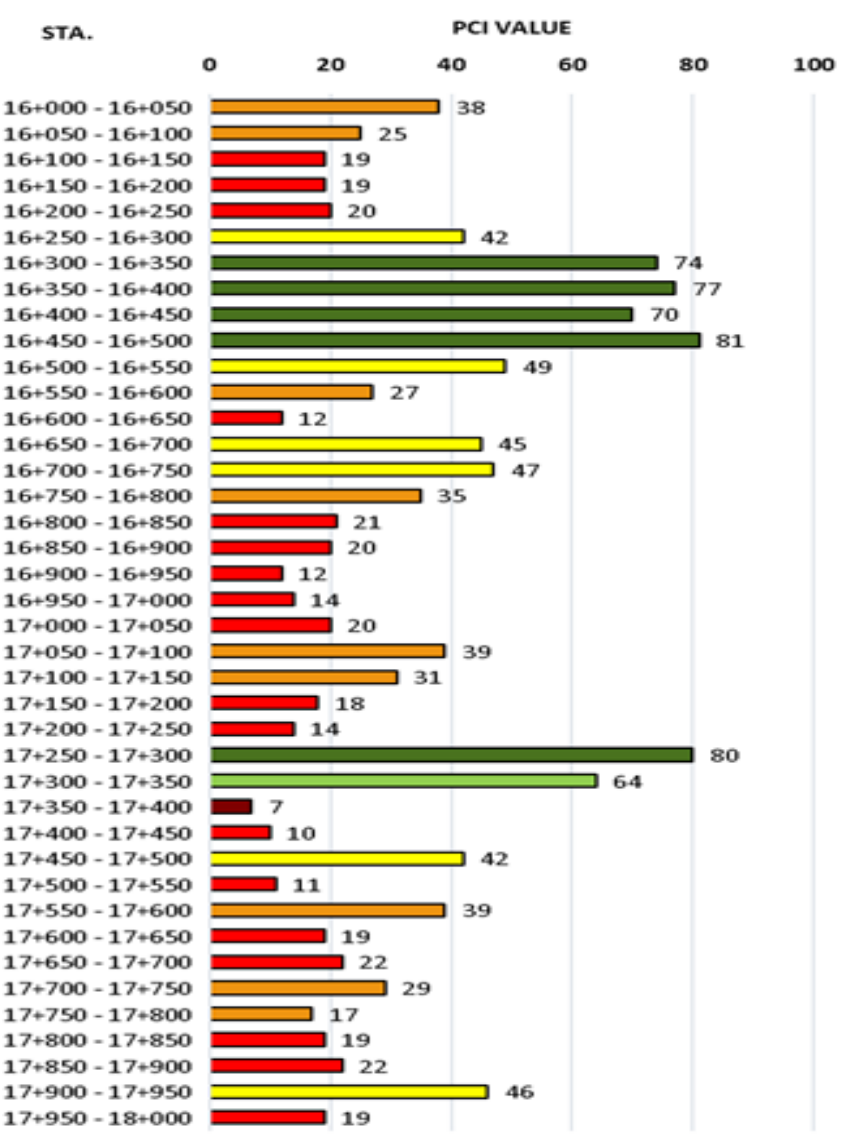

Fig. 15. STA $16+000-$ STA $18+000$

Fig. 14 and 15 show the PCI value of the Triwidadi road for each $4 \mathrm{~km}$ segment. From the color, it is clear that four segments show that the road is included in the failed category, namely at sta. $15+200-15+250,15+350-15+400,15+$ $500-15+550$, and $17+350-17+400$ PCI values of 7,3,8 and 7 , respectively. Also, 27 roads are serious, 21 very poor, 16 poor, five fair, and the remaining seven are satisfactory.

\subsection{The Classification of Pavement Quality}

Fig. 16 illustrates the average value of PCI of 34.75 belonging to a very poor category.

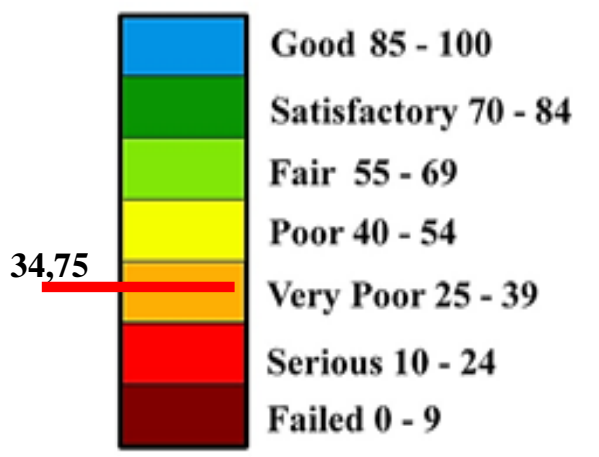

Fig. 16 Average value of PCI

\subsection{Time of Treatment}

Survey was conducted in 2017, while PCI is a quick method for comparing overall pavement conditions and the magnitude of rehabilitation need [12]. Since the road is local, the recommended optimum time for repair or reconstruction is now. In short, the PCI value is appropriate for handling timing assessment if the road is damaged.

Table III. According to PCI Decision matrix

\begin{tabular}{|c|c|c|c|c|}
\hline $\begin{array}{l}\text { Time Of } \\
\text { Improvement }\end{array}$ & Freeway & Arterial & Collector & Local \\
\hline Adequate & $>85$ & $>85$ & $>80$ & $>80$ \\
\hline 6 To 10 Years & 76 To 85 & 76 To 85 & 71 To 80 & $\begin{array}{c}66 \text { To } \\
80\end{array}$ \\
\hline 1 To 5 Years & 66 To 75 & 56 To 75 & 51 To 70 & $\begin{array}{c}46 \text { To } \\
65\end{array}$ \\
\hline $\begin{array}{c}\text { Now } \\
\text { Rehabilitate }\end{array}$ & 60 To 65 & 50 To 55 & 45 To 50 & $\begin{array}{c}40 \text { To } \\
45\end{array}$ \\
\hline $\begin{array}{c}\text { Now } \\
\text { Reconstruct }\end{array}$ & $<60$ & $<50$ & $<45$ & $<40$ \\
\hline
\end{tabular}

Source: [13]

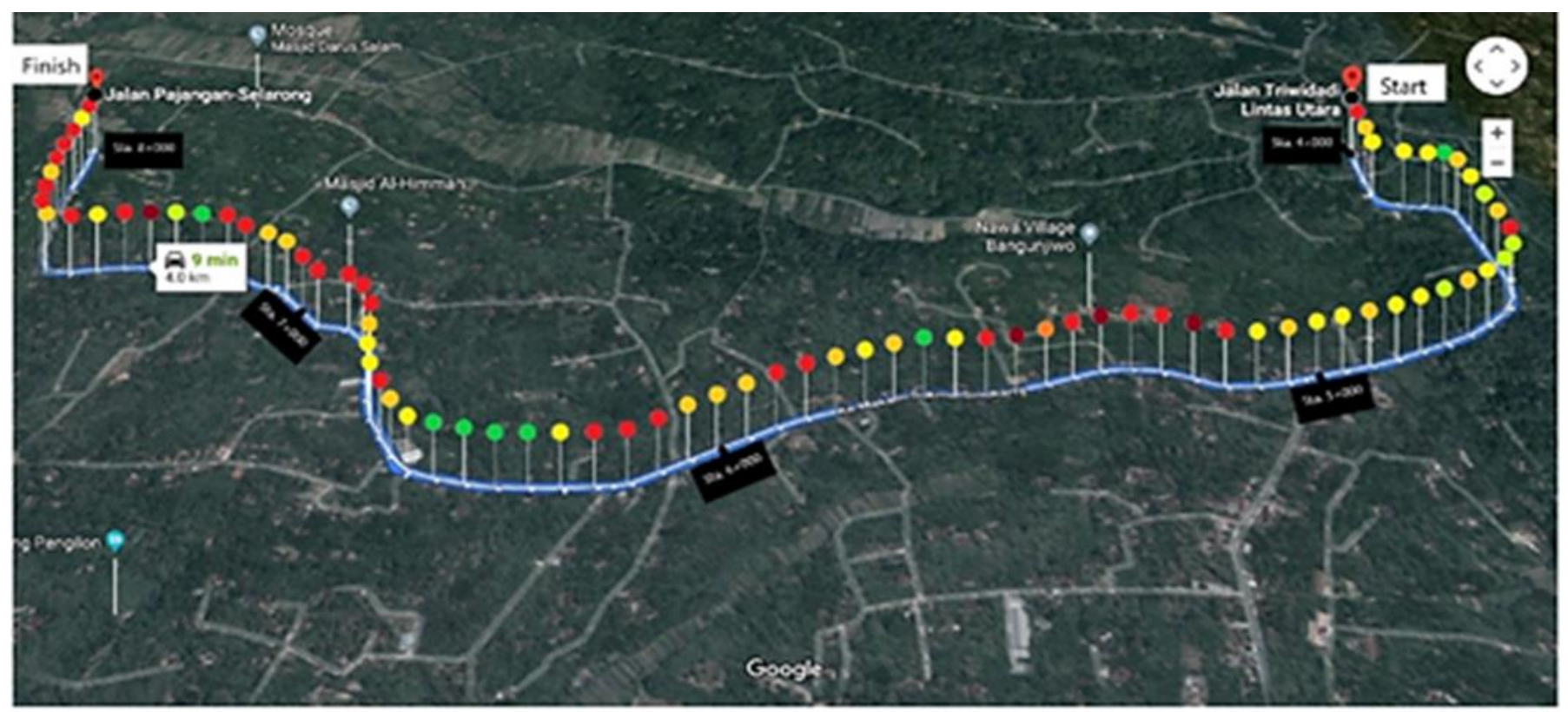

Fig. 17. Stripping map pavement condition index with colour indicator 
The description of Table III and the road index results imply that if not currently reconstructed or repaired, the functional service level will worsen and can cause structural damage. Simultaneously, the driver factor will interfere with the comfort of riders, which will be related to safety.

Fig. 17 above illustrates the analysis results stripping map using a $4 \mathrm{~km}$ long PCI in each section. These roads can be said to have damage. The farther the road, the more visible the road condition is colored red, which indicates the road is serious.

Pavement evaluation was carried out to determine the condition on the surface and structural adequacy. According to [8], the data obtained from such studies were utilized to define the type of maintenance operations required to prioritize maintenance works and establish a pavement maintenance management system.

Maintenance works and establish a pavement maintenance management system. The critical limit value of the PCI could be determined to select the appropriate time of road handling for the segment examined. Based on the critical limitation, the graph was developed to predict the remaining service life based on PCI values [14].

\section{CONCLUSION}

The average value of the Pavement Condition Index (PCI) on Triwidadi Street, Pajangan, Bantul was 34.75, classified as very poor. Since the road is local, the recommended optimum time for reconstruction is now.

The highest percentage of damage was Longitudinal Crack with $22.07 \%$. According to PCI Decision Matrix, this condition means that Triwidadi road needs optimum time of treatment. The correlation between the PCI method and the percentage of damage is that this method utilizes three factors, such as the damage types, the damage severity, and the amount or density of damage.

\section{ACKNOWLEDGMENT}

Thank you very much to the Direktorat Riset dan Pengabdian Kepada Masyarakat in 2017 to finance this research. Thanks to the team, the students involved, I would also like to express my deep gratitude so that this research can run properly even with obstacles, but we can all face it together.

\section{REFFERENCES}

[1] S. Nurjanah Ahmad, T. Harianto, L. Samang, And M. Hustim, "Level Vulnerability Damage Of Pavement Using Pavement Condition Index Method," Matec Web Conf., Vol. 181, P. 11003, 2018.
[2] F. Muhammad, A. Setyawan, And S. Suryoto, "Evaluasi Nilai Kondisi Perkerasan Jalan Nasional Dengan Metode Pavement Condition Index (PCI) Menggunakan Aplikasi Road Evaluation And Monitoring System (Rems) (Studi Kasus : Ruas Jalan Prambanan - Pakem).," Matriks Tek. Sipil, Vol. 7, No. 1, Jun. 2019.

[3] F. G. Faris And M. D. Mahir, "Using Of Modern GIS In Road Condition Index,” Vol. 2, No. 3, P. 13, 2012.

[4] E. Adly, W. Widodo, And A. Rahmawati, "Rehabilitation Planning For Flexible Pavement Using Rebound Deflection Method And PCI Method On Triwidadi Road of Yogyakarta," Int. J. of Integrated Engineering, Vol. 11, No. 9, Pp. 202-211, 2019.

[5] A. Setyawan, J. Nainggolan, And A. Budiarto, "Predicting The Remaining Service Life Of Road Using Pavement Condition Index," Procedia Eng., Vol. 125, Pp. 417-423, 2015.

[6] Tighe,S., Karim,M, Herring, A., Chee,K., Moughabghab, M., and Eng, P., Aviation Administration Word Wide Airport Technology Ttansfer Conference, Atlantic City, New Jersey, USA, 2004.

[7] U. Tho'atin, A. Setyawan, And M. Suprapto, "Penggunaan Metode International Roughness Index (IRI), Surface Distress Index (SDI) Dan Pavement Condition Index (PCI) Untuk Penilaian Kondisi Jalan Di Kabupaten Wonogiri," No. 8 November 2016, P. 9.

[8] A. D. Limantara, S. Winarto, And S. W. Mudjanarko, "Sistem Pakar Pemilihan Model Perbaikan Perkerasan Lenturberdasarkan Indeks Kondisi Perkerasan (PCI)," No. 1-2 November 2017, P. 9.

[9] E. Uglova And S. Saenko, "Review Of Longitudinal Pavement Roughness Prediction Tools," Russ. J. Transp. Eng., Vol. 3, No. 4, Oct. 2016.

[10] "Google Maps," 2019.

[11] ASTM D6433-07, Standard Practice for Roads and Parking Lots Pavement Condition Index Surveys, ASTM International, United States, 48 pp, 2007.

[12] Vishwanath, G., Mahdev, M. R., Archana and Biligiri, K. P., (2013), Development of Pavement Management Strategies for Arterial Roads, International Journal of Research in Engineering and Technology, P174-179.

[13] Hardiyatmo. H.C. Pemeliharaan Jalan Raya (Perkerasan, Drainase, Longsoran) Edisi Kedua, Yogyakarta: Gadjah Mada University Press. 12, 2015.

[14] Stephen A. Arhin, Lakeasha N. Williams, Asteway Ribbiso, And Melissa F. Anderson, "Predicting Pavement Condition Index Using International Roughness Index In A Dense Urban Area," J. Civ. Eng. Res., Vol. 5(1), Pp. 10-17, 2015. 